

\section{Sumário}

UMA PERSPECTIVA COMPARADA ACERCA DA (NÃO) EFETIVIDADE DA DEMOCRACIA LOCAL NO BRASIL E EM Portugal. .................................................................................................... 12 Matheus Passos Silva

A “ATIVIDADE-AÇÃO” PUNITIVO-DISCIPLINAR. INTERATIVIDADE E COMPLEXIDADE ENTRE ATO, PROCEDIMENTO E PROCESSO ADMINISTRATIVO

Sandro Lucio Dezan e Paulo Afonso Cavichioli Carmona

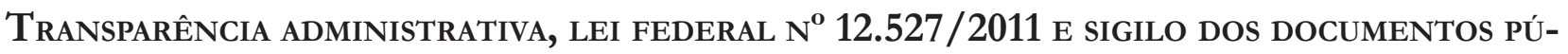
Blicos: A inconstitucionalidade dAS RESTRições AO ACESSO À INFORMAÇÃo....................46 Emerson Affonso da Costa Moura

A influência do Direito Administrativo Global no processo brasileiro de ContrataÇão Pública à luz do Princípio da Transparência .66 Alice Rocha da Silva e Ruth Maria Pereira dos Santos

Interna Corporis Acta e os limites do controle Judicial dos Atos legislativos..........90 Cintia Garabini Lages

A Releitura do PRINCíPIO dA ACTIO NATA QUANTO AOS DiREITOS DifUSOS NA JUDiCIALIZAÇÃo BRASILEIRA 105 Luiz Gustavo Gonçalves Ribeiro e Lorena Machado Rogedo Bastianetto

A Defensoria pública como garantia constitucional Processual de aCESSo À JustiÇa Na AMÉrica do Sul 117 Antonio Henrique Graciano Suxberger e Alberto Carvalho Amaral 
A política de assistênCia social e a promoção ao trabalho: uma ANÁlise do PRONATEC BSM COM BASE EM UM ESTUdo COM EgRESSOS EM ForTALEZA-CE

Aline de Araújo Araújo Martins e Mônica Duarte Cavaignac

INTERVENÇÃo ESTATAL NA AGRICULTURA: A POSSIBILIDADE DE UMA AÇão ÉTICA A FIM DE MATERIALIZAR A CONSTITUIÇÃO BRASILEIRA............................................................ 164

Davi Augusto Santana de Lelis e Giovani Clark

Agricultura orgânica: SOlUÇão Para o SÉCulo XXI? 185

Eloir Trindade Vasques Vieira, Denilson de Oliveira Guilherme, Luis Carlos Vinhas Itavo e Lucelia da Costa Nogueira Tashima

Os DESAFIos JURÍdicos E ECONÔMICOS DA AVIAÇão REgIONAL NO BRASIL

Pablo Leurquin e Mariana Magalhães Avelar

Homeschooling No Brasil: CONFORMAÇÃo DEÔNTICO-AXIOLÓGICA do SISTEMA JURÍdico COMO PLUS À POLÍTICA PÚBLICA DE EDUCAÇÃO FUNDAMENTAL.

Cláudio Márcio Bernardes, Carlos Alberto Simões Tomaz

BARREIRAS À CIDADANIA NAS POlítiCAS SOCIAIS PARA A POPULAÇão EM SITUAÇÃo DE RUA........237 Luciano Roberto Gulart Cabral Júnior e José Ricardo Caetano Costa

O CORTE DO FORNECIMENTO DE ÁGUA EM FACE DO INADIMPLEMENTO DO CONSUMIDOR: ANÁLISE À LUZ DO DIÁlOgo DAS FonTES 251 Leonardo Roscoe Bessa e Gabriela Gomes Acioli César

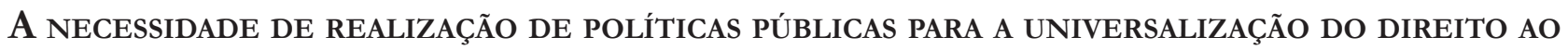
SANEAMENTO BÁSICO

Ruth Santos e Renata Menezes 


\title{
Homeschooling no Brasil: conformação deôntico-axiológica do sistema jurídico como plus à política pública de educação fundamental*
}

\author{
Homeschooling in Brazil: deontic-axiological \\ conformation of the legal system as a plus to \\ the basic education public policy.
}

\author{
Cláudio Márcio Bernardes** \\ Carlos Alberto Simões Tomaz***
}

\section{Resumo}

Tem-se entendido que o ensino domiciliar, movimento social mundialmente conhecido como Homeschooling, não é permitido no Brasil. Por outro lado, considerando-se o aumento no número de adeptos ao fenômeno, torna-se imperioso ampliar o debate para entendê-lo como parte de um importante processo de evolução social. Para cumprir esse propósito, será feita uma abordagem das regras e dos princípios, tomando-se por base a dimensão deontológica e axiológica das relações sociais em face da normatividade vigente. Para tanto, a abordagem ampara-se na lógica dedutiva com exame analítico e sistemático do contexto normativo e de aportes teoréticos a guisa de validar a conclusão no sentido de conformar o homeschooling com o sistema jurídico brasileiro.

Palavras-chave: ensino domiciliar; ensino escolarizado; princípios; regras.

* Recebido em 13/07/2016 Aprovado em 22/09/2016

** Possui graduação em Letras - Português e Inglês pela Fundação Educacional de Divinópolis (1995), especialização em Linguística pela Faculdade São Luís (SP), graduação em Direito pela Fundação Universidade de Itaúna (2005) e especialização pelo Centro Universitário Newton Paiva (2006), Mestrado em Direito pela Universidade de Itaúna (em andamento). Tem experiência na área de Letras, com ênfase em Língua Portuguesa e na área de Direito Público. E-mail: claudiombernardes@yahoo.com.br

*** Professor da Universidade de Itaúna. Email: carlos.simoes@trf1.jus.br

\section{Abstract}

Homeschooling, social movement known worldwide, is not legally permitted in Brazil. On the other hand, considering the increase in the number of followers to the phenomenon, it is imperative to broaden the debate to understand it as part of a important process of social evolution. To this purpose, it's necessary an approach of rules and principles, based on axiological and ethical dimension of social relations. Therefore, the approach seeks refuge in deductive logic with analytical and systematic examination of the regulatory framework and theoretic contributions to validate the homeschooling with the Brazilian legal system.

Keywords: homeschooling; schooled education; principle; rules.

\section{INTRODUÇÃo}

Sob a perspectiva do Estado Democrático de Direito, algumas questões, em um regime autoritário, não teriam ambiente favorável, possibilitam deba- 
tes jurídicos e suscitam teses das mais variadas fontes. Esse contexto se torna mais efetivo, dada a superação da dicotomia Direito público e Direito privado, como salienta Almeida, evidenciado pela nova summa divisio constitucionalizada no País, que enumera, de forma aberta e flexível, os direitos fundamentais individuais e os coletivos previstos no artigo $5^{\circ}$ da $\mathrm{CF} / 88^{1}$.

Sob esse aspecto, a Constituição da República de 1988 garantiu o direito fundamental à educação, como dever da família, da sociedade e do Estado, cuja responsabilidade é corroborada no artigo 205 da Constituição. Como previsto no referido artigo, a Constituição menciona direito à educação e elege os atores principais garantidores desse direito: a Família, o Estado e a Sociedade. Nesse ponto, cabe uma investigação acadêmica acerca das responsabilidades desses entes, em especial no que diz respeito ao dever da família de proporcionar o ensino dos seus filhos, sobremodo, se ele pode ou deve ser concorrente com a educação estatal.

O sistema jurídico brasileiro elegeu o Estado como o grande provedor da educação fundamental. Coube às famílias o papel de coadjuvante no que diz respeito ao ensino. As sanções específicas em caso de descumprimento dessa obrigação visam atingir pais negligentes, que não se preocupam com a instrução dos seus filhos, o que descortina a possibilidade de as famílias, que não se encaixem nessa configuração, proverem tais estudos no âmbito doméstico, de forma concorrente. Uma discussão analítica das regras e dos princípios pode lançar luz ao tema e, quem sabe, trazer alguma contribuição para uma mudança de paradigma quanto ao oferecimento exclusivo do ensino tradicional praticado no País. Para tanto, a lógica dedutiva será utilizada com base em exame analítico-sistemático da regência normativa que envolve a matéria e, se amparando em aportes da doutrina especializada, o presente artigo foi divido em cinco tópicos a guisa de viabilizar, com base nesse viés metodológico, o exame da matéria. No primeiro, será conceituado o ensino doméstico, como um fenômeno social que vem crescendo no Brasil e no mundo. Em seguida, a Teoria do Status de Jellinek será abordada no âmbito do direito-dever à educação fundamental. Importante, também, será falar do ensino escolarizado oferecido pelo Estado na Constituição da República de 1988. No quarto tópico, o ensino domiciliar será entendido como um dos pilares do direito à liberdade individual. Em última análise, numa visão deôntico-axiológica, serão avaliadas dialogicamente as regras e os princípios que preceituam a (im) possibilidade do ensino domiciliar no Brasil. A conclusão aposta na possibilidade do homeschooling no Brasil como um plus à política pública de educação fundamental.

\section{O ENSINO domÉSTICO: UM FENÔMENO SOCIAL QUE VEM CRESCENDO NO BRASIL E NO MUNDO}

Existe, no Brasil e em outros vários países, uma tendência voltada para o ensino doméstico ou domiciliar. Em inglês o ensino que se dá no domicílio do aluno por intermédio de um familiar ou por pessoa que com ele habite é chamado de homeschooling. Diverso do ensino tradicionalmente oferecido, em que uma instituição pública, privada ou cooperativa tem funcionamento espacial previamente definido, sendo todas fiscalizadas por entes estatais.

Em alguns países como Estados Unidos, Áustria, Bélgica, Canadá, Austrália, França, Noruega, Portugal, Rússia, Itália e Nova Zelândia, o ensino doméstico é legalizado. Em outros, proibido, como na Alemanha e na Suécia. Onde é permitido, costuma-se exigir uma avaliação anual dos alunos que recebem educação domiciliar.

No Brasil, não há previsão explícita dessa possibilidade pedagógica, cabendo aos pais ou responsável matricularem, obrigatoriamente, seus filhos entre os 4 e 17 anos em uma escola pública, privada ou em regime de cooperativa. As crianças já devem ser matriculadas na educação infantil a partir dos quatro anos e permanecer na escola até os dezessete, segundo a Lei no 9.394, de 20 de dezembro de 1996 (Lei de Diretrizes e Bases da Educação Nacional).

1 ALMEIDA, Gregório Assagra de. Direito material coletivo: superação da summa divisio clássica direito público e direito privado por uma nova summa divisio constitucionalizada. Belo Horizonte: Del Rey, 2008. 
$\mathrm{Na}$ medida em que o legislador foi silente quanto ao assunto, e houve um recrudescimento do ensino domiciliar no País, a matéria foi colocada pauta de discussão, sobretudo no momento em que o Judiciário, sistematicamente, tem aplicado sanções aos pais educadores, sob a alegação, entre outras cominações, de abandono intelectual. O que será visto mais adiante.

\section{A teoria do status de Jellinek no Âmbito do diReito-deVer À educaÇão fundamental}

Para entender um dispositivo normativo necessário, faz-se necessário inseri-lo num determinado contexto socio-histórico-cultural. Retirar essa análise precedente seria o mesmo que considerar o texto normativo como sendo friamente um signo linguístico, dissociado dos seus significados.

Nessa concepção de língua como código - portanto, como mero instrumento de comunicação - e de sujeito como (pre) determinado pelo sistema, o texto é visto como simples produto da codificação de um emissor a ser decodificado pelo leitor/ouvinte, bastando a este, para tanto, o conhecimento do código utilizado².

O contexto, portanto, pode fornecer os elementos necessários para o entendimento desses sentidos produzidos. Koch e Elias relembram que Van Dijk define contexto como sendo "o conjunto de todas as propriedades da situação social que são sistematicamente relevantes para a produção, compreensão ou funcionamento do discurso e de suas estruturas"3.

Nesse processo de interação entre o receptor e o leitor, no que diz respeito ao texto normativo, surge a necessidade de perquirir os elementos textuais constitutivos para ir além do significante, que representa meramente o código. Durante o processo de leitura, alguns aspectos de divergência costumam ser identificados. Ficar na superfície do texto, por exemplo, pode gerar problemas da ordem da significação, causados pela vagueza de sentido. Ao imergir no contexto, os ruídos podem ser provocados pela ambiguidade, ou seja, mais de um sentido para o mesmo dispositivo. Para a superação desses problemas de ordem comunicativa, autores como Marcelo Neves propõem a interpretação para evitar a ambiguidade e a concretização da norma a ultrapassar a vagueza textual ${ }^{4}$.

Ainda de acordo com o autor,

O processo de passagem da ambiguidade (imprecisão conotativa) prima facie da disposição normativa à superação da vagueza (imprecisão denotativa) exige não propriamente que se "considerem todos os fatores" do contexto, mas que se determine seletivamente se os fatos jurídicos relevantes ao caso enquadram-se na hipótese normativa ${ }^{5}$.

Diante dessas considerações, a hermenêutica da evolução da tutela jurídica do direito fundamental à educação deve ser entendida sobre os diferentes vieses, ainda que de breve passagem, do Estado Liberal de Direito, do Estado Social e do Estado Democrático de Direito.

Quem se propuser a uma análise em profundidade da evolução constitucional do Brasil não terá dificuldade em distinguir três fases históricas perfeitamente identificáveis em relação aos valores políticos, jurídicos e ideológicos que tiveram influxo preponderante na obra de caracterização formal das instituições: a primeira, vinculada ao modelo constitucional francês e inglês do Século XIX; a segunda, representando já uma ruptura, atada ao modelo norte-americano e, finalmente, a terceira, em curso, em que se percebe, com toda a evidência, a presença de traços fundamentais presos ao constitucionalismo alemão do corrente século .

2 KOCH, Ingedore Vilaça; ELIAS, Maria Vanda. Ler e compreender os sentidos do texto. São Paulo: Contexto, 2006. KOCH; ELIAS, 2006, passim.

NEVES, Marcelo. Entre Hydra e Hércules. São Paulo: WMF Martins Fontes, 2013.

NEVES, 2013, passim

BONAVIDES, Paulo. Curso de Direito Constitucional. 29 ed. São Paulo: Malheiros, 2014. 
E, nesse propósito, Alexy considera que a Teoria do Status de Jellinek ajuda a compreender o papel do Estado em relação ao cidadão ${ }^{7}$. Analiticamente, Jellinek ${ }^{8}$ caracterizou o status como sendo: passivo, negativo, positivo e ativo?

O status passivo ou status subiectionis representa uma sujeição do indivíduo ao Estado. Jellinek propõe duas interpretações que implicam essa sujeição. Na primeira, o Estado exerce algum poder de dever ou proibição diante do cidadão. Na segunda, há uma totalidade de deveres e proibições do Estado perante o cidadão. Por estar situado na esfera das obrigações sociais, o status passivo é inerente à estrutura das sociedades modernas, menos presente num Estado Democrático de Direito e mais intervencionista nos regimes autoritários.

O status negativo ou status libertatis pode ser associado à primeira dimensão dos direitos fundamentais, em que se impõe ao Estado uma atitude de abstenção diante dos direitos do cidadão. Corresponde ao Estado Liberal. O status negativo é composto, exclusivamente, de faculdades, de liberdades jurídicas não protegidas. São os direitos de defesa do cidadão a provocar um não-embaraço do Estado. Segundo Jellinek, "a liberdade existe apenas no singular". Todas as ações que não são nem obrigatórias nem proibidas estão no espaço das liberdades.

No status positivo ou status civitatis, o Estado reconhece ao indivíduo "a capacidade jurídica para recorrer ao aparato estatal e utilizar as instituições estatais, ou seja, garante ao indivíduo pretensões positivas". Confere-lhe, ainda, o status cívico quando (1) lhe garante "pretensões à sua atividade" e (2) "cria meios jurídicos para a realização desse fim". O direito do cidadão corresponde à segunda dimensão dos direitos fundamentais, ligados aos direitos sociais, marcados pela igualdade ${ }^{10}$.

No status ativo ou status da cidadania, as capacidades outorgadas ao cidadão pelo Estado, como, por exemplo, o direito de votar e ser votado, o legitimam para participar mais ativamente do Poder. Corresponde à terceira dimensão dos direitos fundamentais em que se destaca a atividade do cidadão, apto a participar do macrossistema, como na ação popular para reparar danos ao meio ambiente ou ao patrimônio público. Pela natureza altruística, pode ser associado à fraternidade.

\section{O ENSINO ESCOLARIZADO GARANTIDO E IMPOSTO PELA FORTE PRESENÇA ESTATAL NA Constituição da República de 1988}

Ao garantir o direito à educação, a Constituição da República de 1988 impôs o dever da família, da sociedade e do Estado em assegurar à criança e ao adolescente o direito à educação e à convivência comunitária, nos seguintes termos:

Art. 227. É dever da família, da sociedade e do Estado assegurar à criança e ao adolescente, com absoluta prioridade, o direito à vida, à saúde, à alimentação, à educação, ao lazer, à profissionalização, à cultura, à dignidade, ao respeito, à liberdade e à convivência familiar e comunitária, além de colocá-los a salvo de toda forma de negligência, discriminação, exploração, violência, crueldade e opressão.

A responsabilidade da família, do Estado e da sociedade é legitimada no artigo 205 da Constituição da República:

Art. 205. A educação, direito de todos e dever do Estado e da família, será promovida e incentivada com a colaboração da sociedade, visando ao pleno desenvolvimento da pessoa, seu preparo para o exercício da cidadania e sua qualificação para o trabalho.

7 ALEXY, Robert. Teoria Dos Direitos Fundamentais. $2^{\text {a }}$ Ed. São Paulo: Malheiros, 2011.

8 JELLINEK, Georg. Systerm der subjecktiven öffentlichen Rechte. Tübingen: Mohr, 1905.

9 JELLINEK, Georg. Allgemeine Staatslehre. Bad Homburg: Gentner, 1960.

10 ALEXY, 2011, passim. 
Tem-se, portanto, a responsabilidade da família, do Estado e da sociedade quanto ao dever de promover a educação. Será necessária, nesse sentido, a participação desses três parceiros (família, Estado e sociedade) para que se possam efetivar os objetivos constitucionais previstos no artigo 205, acerca do pleno desenvolvimento da pessoa, do preparo para o exercício da cidadania e da qualificação para o trabalho.

O Estado brasileiro entendeu que a família, por si só, não poderá atingir esse amplo objetivo constitucional na formação de seus filhos, sem a participação estatal e da sociedade no cumprimento desse dever. Assim, a obrigação da família não exclui a das outras entidades e nenhum tem prioridade sobre o outro.

Por outro, o artigo 208 da Constituição da República aborda a obrigatoriedade da educação básica dos quatro aos dezessete anos de idade, como direito público subjetivo e incumbindo ao Poder Público zelar pela frequência à escola, como segue:

Art. 208. O dever do Estado com a educação será efetivado mediante a garantia de:

$[\ldots]$

I - educação básica obrigatória e gratuita dos 4 (quatro) aos 17 (dezessete) anos de idade, assegurada inclusive sua oferta gratuita para todos os que a ela não tiveram acesso na idade própria;

$[\ldots]$

$\int 1^{\circ}-\mathrm{O}$ acesso ao ensino obrigatório e gratuito é direito público subjetivo.

$\sqrt{ } 2^{\circ}$ - O não-oferecimento do ensino obrigatório pelo Poder Público, ou sua oferta irregular, importa responsabilidade da autoridade competente.

$\int 3^{\circ}$ - Compete ao Poder Público recensear os educandos no ensino fundamental, fazer-lhes a chamada e zelar, junto aos pais ou responsáveis, pela frequência à escola.

Diante da determinação contida no citado artigo 208, o não oferecimento do ensino obrigatório pelo Poder Público, ou sua oferta irregular, importa responsabilidade da autoridade competente. O Poder Público não pode, pois, se eximir da obrigação de buscar o aluno (censo escolar), disponibilizar a matrícula e zelar, junto com os pais, pela sua frequência regular à escola. A Constituição deixa claro, desse modo, a importância da presença do aluno na escola, especialmente na faixa etária relativa ao ensino obrigatório.

O Conselho Nacional de Educação, por meio da Câmara de Educação Básica, analisou a questão da educação domiciliar no Parecer CNE/CEB no 34/2000, homologado em 15/12/2000 e publicado no Diário Oficial da União em 18/12/2000. O citado parecer foi conclusivo no sentido da impossibilidade da educação familiar:

Portanto, família, sociedade, organizações culturais e outras, são todas cooperadoras no desenvolvimento de uma educação plena, visando à plena cidadania. Mas a escola é agência indispensável, na conjugação dos deveres "da família e do Estado", conforme o art. $2^{\circ}$ da LDB. Não da família sem o Estado ou do Estado sem a família, com inspiração "nos princípios de liberdade e nos ideais de solidariedade humana", tendo "por finalidade o pleno desenvolvimento do educando, seu preparo para o exercício da cidadania e sua qualificação para o trabalho". Certamente, foi sábio o legislador, ao envolver a tríade mencionada na consecução de objetivos tão amplos. Porque a família, ela só, jamais reunirá as condições mínimas necessárias para alcançar objetivos tão amplos e complexos.

Os direitos à educação e à cidadania são direitos individuais indisponíveis assegurados pela Constituição e também presentes na legislação infraconstitucional.

Nesse sentido, a Lei 9394/96 (Lei de Diretrizes e Bases da Educação Nacional - LDB) define a abrangência do ensino e determina que a educação ocorra, predominantemente, em instituições próprias:

Art. $1^{\circ}$ A educação abrange os processos formativos que se desenvolvem na vida familiar, na convivência humana, no trabalho, nas instituições de ensino e pesquisa, nos movimentos sociais e organizações da sociedade civil e nas manifestações culturais. 
$\int 1^{\circ}$ Esta Lei disciplina a educação escolar, que se desenvolve, predominantemente, por meio do ensino, em instituições próprias.

$\int 2^{\circ} \mathrm{A}$ educação escolar deverá vincular-se ao mundo do trabalho e à prática social.

A LDB estabelece a obrigação da matrícula, tarefa da qual os pais não podem se omitir:

Art. $6^{\circ}$ É dever dos pais ou responsáveis efetuar a matrícula das crianças na educação básica a partir dos 4 (quatro) anos de idade (Redação dada pela Lei no 12.796, de 2013).

Essa obrigatoriedade, também, está prevista no artigo 55 do Estatuto da Criança e do Adolescente ECA, Lei no 8.069/1990: "Art. 55. Os pais ou responsável têm a obrigação de matricular seus filhos ou pupilos na rede regular de ensino".

Para o caso de omissão dos pais ou responsáveis, que viole ou ameace direitos dos menores, a exemplo da recusa de matrícula objetivando a educação domiciliar, o Estatuto da Criança e do Adolescente prevê a aplicação de medidas protetivas (Artigo 98, inciso II; artigo 129 e artigo 249).

O artigo 24 da LDB prevê a possibilidade de classificação do aluno pela escola, possibilitando a matrícula desse aluno, que tenha iniciado os estudos fora do ambiente escolar, em série compatível com sua idade e nível de conhecimento.

Esse mesmo artigo, também, exige a frequência mínima de 75\% nas 800 horas anuais para a aprovação, dando destaque à presença do aluno na sala de aula.

Art. 24. A educação básica, nos níveis fundamental e médio, será organizada de acordo com as seguintes regras comuns:

I - a carga horária mínima anual será de oitocentas horas, distribuídas por um mínimo de duzentos dias de efetivo trabalho escolar, excluído o tempo reservado aos exames finais, quando houver;

II - a classificação em qualquer série ou etapa, exceto a primeira do ensino fundamental, pode ser feita:

$[\ldots]$

c) independentemente de escolarização anterior, mediante avaliação feita pela escola, que defina o grau de desenvolvimento e experiência do candidato e permita sua inscrição na série ou etapa adequada, conforme regulamentação do respectivo sistema de ensino;

$[\ldots]$

VI - o controle de frequência fica a cargo da escola, conforme o disposto no seu regimento e nas normas do respectivo sistema de ensino, exigida a frequência mínima de setenta e cinco por cento do total de horas letivas para aprovação.

O já mencionado Parecer CNE/CEB no 34/2000 ponderou acerca do artigo 24 da LDB enfocando a necessidade do convívio escolar do educando para sua formação:

Poder-se-ia invocar o art. 24, inciso II, alínea "c", ad argumentandum. Efetivamente, ali está disposto que "independentemente de escolarização anterior mediante avaliação feita pela escola, que defina o grau de desenvolvimento e experiência do candidato e permita sua inscrição na série ou etapa adequada, conforme regulamentação do respectivo sistema", o aluno poderá ser classificado em qualquer série, nos níveis fundamental e médio. Não se trata, obviamente, de um estímulo à desescolarização do ensino. O dispositivo é sábio, visando à viabilização de inserção de alunos desgarrados do processo regular, a qualquer tempo.

Principalmente, em se tratando do ensino fundamental, que é o caso considerado, além dos dispositivos legais enunciados, dos quais o art. $6^{\circ}$ é emblemático, outro merece especial atenção. Trata-se do que se contém no art. 32. O caput, voltando a afirmar que o "ensino fundamental, com duração mínima de oito anos", é obrigatório (e gratuito na escola pública), enuncia, em seus quatro incisos, os objetivos do ensino fundamental. O último deles, ao mesmo tempo que fala no "fortalecimento dos vínculos da família", acrescenta também os laços de solidariedade humana e de tolerância recíproca em que se assenta à vida social". 
Ora, se o fortalecimento dos vínculos da família é de capital significado, não menos importantes são a solidariedade humana, a tolerância recíproca que fundamentam a vida social. E estes, não deverão ser cultivados no estreito (no sentido de limitado) espaço familiar. A experiência do coexistir no meio de outras pessoas, a oportunidade do convívio com os demais semelhantes, tudo são situações educativas que só a família não proporciona e que, portanto, não garante o que a lei chama de preparo para a "cidadania plena".

E mais adiante:

Ao determinar que o ensino fundamental é presencial, na escola, é claro, e que nele se exige um mínimo de $75 \%$ de frequência, a lei enfatizou a importância da troca de experiências, do exercício da tolerância recíproca, não sob o controle dos pais mas no convívio das salas de aula, dos corredores escolares, dos espaços de recreio, nas excursões em grupo fora da escola, na organização de atividades esportivas, literárias ou de sociabilidade, que demandam mais que os irmãos apenas, para que reproduzam a sociedade, onde a cidadania será exercida. Porque o preparo para esse exercício é uma das três finalidades fundamentais da educação. As outras sendo o pleno desenvolvimento do educando e sua qualificação para o trabalho (art. $2^{\circ}$, LDBEN).

O Superior Tribunal de Justiça, em sede do Mandado de Segurança nº. 7.407/DF, de relatoria do Ministro Francisco Peçanha Martins já se posicionou acerca da impossibilidade do ensino domiciliar. A mencionada decisão asseverou que a frequência à escola é direito dos menores, previsto na Constituição Federal e regulamentado pela Lei de Diretrizes e Bases da Educação e pelo Estatuto da Criança, sendo que a referida regulamentação não pode ser excepcionada pela convicção filosófica dos pais. Afirmou, também, que a mera demonstração da capacidade dos pais para o exercício do magistério não é suficiente para excluir os menores do direito ao convívio escolar. E, por fim, ressaltou que o Poder Judiciário não pode desprezar o ordenamento jurídico, a fim de privilegiar as convicções filosóficas dos genitores.

Os filhos não são dos pais, como pensam os Autores. São pessoas com direitos e deveres, cujas personalidades se devem forjar desde a adolescência em meio a iguais, no convívio social formador da cidadania. Aos pais cabem, sim, as obrigações de manter e educar os filhos consoante a Constituição e as leis do País, asseguradoras do direito do menor à escola (art. $5^{\circ}$ e 53, I, da Lei no 8.096/90) e impositivas de providências e sanções voltadas à educação dos jovens como se observa no art. 129, e incisos, da Lei $n^{\circ}$ 8.096/90 supra transcritos, e art. 246, do Código Penal, que define como crime contra a assistência familiar "deixar, sem justa causa, de prover à instrução primária de filho em idade escolar", cominando a pena de "detenção de quinze dias a um mês, ou multa, de vinte centavos a cinquenta centavos". (STJ, Relator: Ministro Francisco Peçanha Martins, Data de Julgamento: 24/04/2002, S1 - Primeira Seção).

Sob o mesmo prisma, alguns tribunais têm condenado os pais sob a alegação de abandono intelectual, arrogando o Art. 246 do Código Penal: "Deixar, sem justa causa, de prover à instrução primária de filho em idade escolar: Pena - detenção, de quinze dias a um mês, ou multa."

JUSTIÇA DA INFÂNCIA E DA JUVENTUDE - EDUCAÇÃO DOS FILHOS - CONCEITO. Promover a educação dos filhos é dever inerente ao pátrio poder, assim como a subordinação dos filhos ao mando paterno. Por educação compreende-se o esforço tendente a promover o desenvolvimento físico, intelectual e moral do indivíduo e ajustá-lo às normas comuns de comportamento. A transição do indivíduo para o cidadão é fruto das práticas educativas, implícitas no instituto em estudo. O Código Penal, art. 246, reprime o crime de abandono intelectual, informado pelo fato de deixar, sem justa causa, de prover a instrução primária de filho em idade escolar... Fora de dúvidas que a subordinação do filho ao mando paterno se inclui no curso ativo da educação. (TJ-SP - Apelação Cível 28180- 0/5 - Acórdão COAD 76534 - Rel. Des. Pereira da Silva - Julgamento em 29-8-1996).

A Constituição de 1988, promulgada num ambiente pós-Ditadura, elegeu o Estado Democrático de Direito para irradiar o ordenamento jurídico nacional. Os direitos fundamentais, cerceados durante o período ditatorial, foram elevados à máxima potência. O direito à liberdade de expressão, por exemplo, sepultou uma era marcada pela censura prévia. Mas, sem dúvida, os direitos sociais são elencados ao longo da Constituição de forma marcante, haja vista o seu primeiro artigo que afirma: “Todo o Poder emana do povo". É por isso que Bonavides afirma: 
A Constituição de 1988 é basicamente em muitas de suas dimensões essenciais uma Constituição do Estado social. Portanto, os problemas constitucionais referentes a relações de poderes e exercício de direitos subjetivos têm que ser examinados e resolvidos à luz dos conceitos derivados daquela modalidade de ordenamento. Uma coisa é a Constituição do Estado liberal, outra a Constituição do Estado social. A primeira é uma Constituição antigoverno e antiestado; a segunda uma Constituição de valores refratários ao individualismo no Direito e ao absolutismo no Poder $^{11}$.

Os direitos sociais previstos na Lei Magna revelam um gigantismo estatal e desnudam a mão de ferro do Estado-Leviatã, onipresente e onipotente. Nesse modelo, o status passivo mencionado por Jellinek aparece a toda evidência. $\mathrm{O}$ cidadão se submete aos comandos estatais, esperando sempre uma prestação positiva. Abre-se caminho para governos populistas e caudilhos aventureiros. A educação sofre essa intervenção, estando quase exclusivamente sob o controle do Estado, seja pela construção e manutenção de escolas públicas, seja na regulação e fiscalização das escolas privadas, ditando-lhes inclusive as disciplinas a lecionar. Essa ubiquidade é deletéria na medida em que se consideram as avaliações internacionais a que o Brasil tem-se submetido. No último Programa Internacional de Avaliação de Alunos, Pisa (2014), por exemplo, que avaliou a capacidade de 85 mil estudantes do mundo inteiro, na faixa etária de 15 anos, para resolver problemas de matemática aplicados à vida real, o Brasil ficou em $38^{\circ}$ lugar, com 428 pontos, em um total de 44 países. Os dados disponíveis no sítio do Instituto Nacional de Estudos e Pesquisas Educacionais Anísio Teixeira, INEP (1 de abril de 2014), do Governo Federal, revelam que o ensino estatal evoluiu, mas está longe de ser comparado aos países que são excelência no assunto, como Cingapura, China e Japão. Um dos problemas apontados por educadores para essa defasagem de ensino reside nos Parâmetros curriculares que engessam os currículos, padronizam materiais didáticos e adotam as mesmas estratégias pedagógicas num país de dimensão continental, com as suas idiossincrasias culturais, que se mostram diversas e complexas. E o Estado, definitivamente, não tem obtido êxito no confronto com essas diversidades.

À medida que se revele exitosa a prática pedagógica adotada pelos pais no âmbito doméstico, acaba-se criando um comparativo com o ensino oferecido pelo Estado. E suas mazelas já conhecidas pelo senso comum e traduzidas nas avaliações internacionais tornam-se cada vez mais evidentes.

\section{A liberdade indiVIDUAL de OS PRÓPRIOS PAis PROMOVEREM O ENSINO dOS SEUS FILHOS NO ÂMBITO DOMÉSTICO - HOMESCHOOLING}

A educação domiciliar aparecia em linhas gerais na Constituição de 1937. Surgia como direito primordial dos pais e apresentava o caráter meramente colaborativo da atuação estatal. Refletia, portanto, o Estado liberal, destacando a família como ente essencial para a educação dos filhos.

Art. 125 - A educação integral da prole é o primeiro dever e o direito natural dos pais. O Estado não será estranho a esse dever, colaborando, de maneira principal ou subsidiária, para facilitar a sua execução ou suprir as deficiências e lacunas da educação particular.

A Declaração Universal dos Direitos Humanos, adotada e proclamada pela Resolução no 217 A (III) da Assembleia Geral das Nações Unidas em 10 de dezembro de 1948, assinada pelo Brasil na mesma data, estabeleceu o direito à liberdade de escolha dos pais quanto à educação dos seus filhos. Em seu Artigo 26, \$3, preceitua que: "os pais têm prioridade de direito na escolha do gênero de instrução que será ministrada a seus filhos". Essa liberdade representa a autonomia individual do cidadão em face do Estado-provedor.

A consideração do indivíduo como sujeito da autonomia individual, moral e intelectual (essência da filosofia das luzes), justificará a exigência revolucionária da constatação ou declaração dos direitos do homem, existentes a priori. O sentido destas declarações não se reconduzia à reafirmação de uma teoria da tolerância, ou seja, de apelos morais dirigidos ao soberano, tendentes a obter garantias para os súditos.

11 BONAVIDES, 2014, passim. 
A tolerância ficava sempre no domínio reservado do soberano e, consequentemente, na sua completa disponibilidade. As declarações dos direitos vão mais longe: os direitos fundamentais constituem uma esfera própria e autônoma dos cidadãos, ficam fora dos ataques legítimos do poder e contra o poder podiam ser defendidos ${ }^{12}$.

Os direitos fundamentais liberais costumam ser entendidos como um mecanismo de resistência às intervenções autoritárias por parte do Estado.

Neste contexto, os direitos fundamentais liberais decorriam não tanto de uma declaração revolucionária de direitos mas do respeito de uma esfera de liberdade individual. Compreende-se, por isso, que os direitos fundamentais - liberdade e propriedade (Freibeit und Eigentum) - só pudessem sofrer intervenções autoritárias por parte da administração quando tal fosse permitido por uma lei aprovada pela representação popular (doutrina da lei protectora dos direitos de liberdade e de propriedade e doutrina da reserva de lee). (CANOTILHO, 2003, p. 97)

Com o avanço da legislação brasileira, abalizado pelo processo de redemocratização, os pais ficaram responsáveis por colocar as crianças na educação infantil a partir dos quatro anos e por sua permanência até os 17 anos (Lei de Diretrizes e Bases da Educação Nacional). O artigo 1.634 do Código Civil Brasileiro assevera que compete aos pais, quanto aos filhos menores, dirigir-lhes a criação e a educação. $\mathrm{O}$ artigo 22 do Estatuto da Criança e do Adolescente (ECA) prevê que aos pais incumbe o dever de sustento, guarda e educação dos filhos menores. Nas entrelinhas, lê-se a influência da Constituição de 1937 nos referidos artigos. Nesses trechos lançou-se luz à importância dos pais no processo de educação dos seus filhos. A Constituição menciona o dever do Estado e da família como provedores da educação fundamental, mas não descreve o papel de cada ente, cabendo-lhes, pois, a função cooperativa. Já a legislação infraconstitucional, como visto, prevê a obrigação dos pais de matricularem seus filhos na escola e, ainda, a possibilidade de sanção quanto ao seu descumprimento.

Andrade, em tese defendida no doutorado da Universidade de São Paulo (USP), aborda essa lacuna constitucional ${ }^{13}$.

Como vimos, excetuando um dever que vem sendo interpretado, a contrario sensu, como um dever dos pais ou responsáveis da criança por matriculá-la e zelar por sua frequência à escola, não há, na Constituição Federal, nenhuma obrigação específica atribuída à família, apenas se declara o seu dever em promover a Educação Nacional, sem especificar como. Ao mesmo tempo, existem muitas obrigações delineadas quanto ao Estado. É na LDB que surge o comando dirigido aos pais das crianças e adolescentes quanto a matricular e zelar pela frequência de seus filhos à escola.

Conforme já delineado, em uma leitura prima facie de toda a legislação nacional, a função primordial dos pais na educação de seus filhos consiste em matriculá-los em uma escola, pública ou privada, mantendo-os com frequência regular. O restante fica por conta do Estado-provedor. Para corrigir essa desproporcionalidade, a Câmara dos Deputados recolocou em pauta o Projeto de Lei no 3179/2012, de autoria do Deputado Lincoln Portela. Nele, fica admitido o ensino no âmbito doméstico, ministrado por pais ou tutores responsáveis pelos estudantes.

Art. $1^{\circ} \mathrm{O}$ art. 23 da Lei no 9.394 , de 20 de dezembro de 1996, passa a vigorar acrescido do seguinte parágrafo:

Art. $23[\ldots]$

$\int 3^{\circ}$ É facultado aos sistemas de ensino admitir a educação básica domiciliar, sob a responsabilidade dos pais ou tutores responsáveis pelos estudantes, observadas a articulação, supervisão e avaliação periódica da aprendizagem pelos órgãos próprios desses sistemas, nos termos das diretrizes gerais estabelecidas pela União e das respectivas normas locais.

12 CANOTILHO, José Joaquim Gomes. Direito Constitucional e Teoria da Constituição. Almedina: São Paulo. 2003.

13 ANDRADE, Édison Prado de. A educação familiar desescolarizada como um direito da criança e do adolescente: relevância, limites e possibilidades na ampliação do direito à educação. Tese de doutorado da Universidade de São Paulo (USP), orientação: Roberto da Silva, São Paulo: s.n., 2014. Disponível em: http://www.teses.usp.br/teses/disponiveis/48/48134/tde-10112014111617/pt-br.php. Acesso em 10/07/2015. 
$\mathrm{Na}$ Justificação do Projeto, é patente a intenção do legislador de ampliar a responsabilidade do ensino, atualmente concentrada nas mãos do Estado, para a família, afiançando-lhe o direito-dever de educar os filhos: "Garantir na legislação ordinária essa alternativa é reconhecer o direito de opção das famílias com relação ao exercício da responsabilidade educacional para com seus filhos”.

Recentemente, nesse mesmo passo, o Supremo Tribunal Federal admitiu, em sede de Recurso Extraordinário, a repercussão geral do assunto aqui discutido.

Ementa: DIREITO CONSTITUCIONAL. EDUCAÇÃO. ENSINO DOMICILIAR. LIBERDADES E DEVERES DO ESTADO E DA FAMÍLIA. PRESENÇA DE REPERCUSSÃO GERAL. 1. Constitui questão constitucional saber se o ensino domiciliar (bomeschooling) pode ser proibido pelo Estado ou viabilizado como meio lícito de cumprimento, pela família, do dever de prover educação, tal como previsto no art. 205 da CRFB/1988. 2. Repercussão geral reconhecida. (STF, Recurso Extraordinário (RE) 888815, TJRS, ministro-relator Luís Roberto Barroso, 15 de maio de 2015).

O recurso fundamentou-se no art. 102, III, a, da Constituição Federal. A parte recorrente alegou violação aos arts. 205, 206, 208, 210, 214 e 229, da Constituição.

Restringir o significado da palavra educar simplesmente à instrução formal numa instituição convencional de ensino é não apenas ignorar as variadas formas de ensino - agora acrescidas de mais recursos com a tecnologia - como afrontar um considerável número de garantias constitucionais, cujo embasamento se dá, entre outros, pelos princípios da liberdade de ensino (art. 206, II, CF) e do pluralismo de ideias e de concepções pedagógicas (art. 206, III, CF), tendo-se presente a autonomia familiar assegurada pela Constituição.

O ministro-relator, Luís Roberto Barroso, reconhece a concorrência do direito fundamental da educação como dever do Estado e da família. O artigo 208 da Constituição tão somente apresenta a obrigação estatal: "a controvérsia envolve, portanto, a definição dos contornos da relação entre Estado e família na educação das crianças e adolescentes, bem como os limites da autonomia privada contra imposições estatais".

Em sua conclusão, o ministro reconhece a repercussão geral do assunto sob dois enfoques: 1) a liberdade pedagógica dos pais em relação ao ensino dos seus filhos e em respeito às suas convicções axiológicas e 2) os limites de atuação do Estado, respeitando, justamente, essa liberdade:

O debate apresenta repercussão geral, especialmente do ponto de vista social, jurídico e econômico: social, em razão da própria natureza do direito pleiteado; jurídico, porque relacionado à interpretação e alcance das normas constitucionais que preveem a liberdade de ensino e o pluralismo de ideias e concepções pedagógicas e à definição dos limites da relação entre Estado e família na promoção do direito fundamental à educação; e econômico, tendo em conta que, segundo estudos o reconhecimento do homeschooling poderia reduzir os gastos públicos com a educação (STF, Recurso Extraordinário (RE) 888815, TJRS, ministro-relator Luís Roberto Barroso, 15 de maio de 2015).

Espera-se que o STF, ante tão fortes e relevantes argumentos, abra, inclusive, espaço dialógico em audiência pública para a manifestação de todos os interessados.

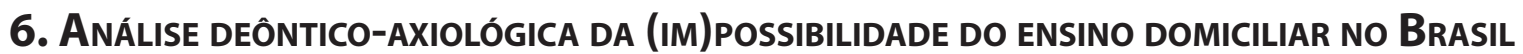

A evolução jurídica nas sociedades contemporâneas reflete os modelos axiológicos por elas adotados. Não há falar em uma moral absoluta, que atenda aos diferentes propósitos humanos. Da mesma forma, não se pode vislumbrar dispositivos normativos que deem conta de todas as idiossincrasias sociais. Basta imaginar a discussão atual da união homoafetiva para entender como as regras e os princípios se transformam para se amoldarem à dinâmica social. O contrário disso não se aplica.

$\mathrm{Na}$ sociedade moderna, os pontos de observação se multiplicam cada vez mais, sendo inusitado que se possa falar de um ideal regulativo capaz de descortinar o consenso subjacente na moralidade comunitária. 
Antes se impões discutir quais são os processos e estruturas normativos adequados à absorção legítima do dissenso estrutural presente na esfera pública a respeito da determinação dos direitos e deveres constitucionais. A articulação paradoxal de princípios e regras na cadeia (talvez seja melhor na rede) argumentativa da concretização constitucional tem um importante papel nesse contexto ${ }^{14}$.

As críticas de Alexy quanto à tese de que as regras são aplicadas à maneira do "tudo-ou-nada", abarcando todas as possibilidades através das normas de exceção, são adequadas para entender essa evolução social $^{15}$. Nenhum sistema jurídico possui a competência de regramento exaustivo tampouco é capaz de criar exceções enumeráveis fatuais ou contrafatuais. A qualquer pessoa que leia, prima facie, o artigo 155 do Código Penal não caberia outra interpretação do dispositivo que não fosse a responsabilização penal pelo crime de furto. No entanto, como o legislador não tem o condão de imaginar todas as hipóteses de exceção e, convenhamos, seria impossível a sua previsão absoluta, cabe ao juiz a melhor interpretação da Lei na subsunção do fato à norma. Nesse campo da aplicação do artigo 155 do Código Penal, tem-se levado em conta o princípio da insignificância para excluir a punibilidade do autor. Ora, se o agente subtraiu para si coisa alheia móvel, no campo do "tudoou nada", não interessaria o pequeno valor do bem. Em várias decisões judiciais, não é esse o entendimento, ampliando-se as possibilidades de diálogo com o catálogo de princípios disponíveis no ordenamento jurídico.

Ementa: PENAL. AGRAVO REGIMENTAL NO RECURSO ESPECIAL. TENTATIVA DE FURTO. PRINCÍPIO DA INSIGNIFICÂNCIA. DIMINUTO VALOR. RESTITUIÇÃO À VÍTIMA. PREPONDERÂNCIA SOBRE A REITERAÇÃO DELITIVA. AGRAVO PROVIDO. 1. Sedimentou-se a orientação jurisprudencial no sentido de que a incidência do princípio da insignificância pressupõe a concomitância de quatro vetores: a) mínima ofensividade da conduta do agente; b) nenhuma periculosidade social da ação; c) reduzidíssimo grau de reprovabilidade do comportamento e d) inexpressividade da lesão jurídica provocada. 2. A reiteração delitiva tem sido compreendida como obstáculo inicial à tese da insignificância, ressalvada excepcional peculiaridade do caso penal. 3. Em razão da coisa que se tentou furtar (dois cosméticos), seu diminuto valor (R \$ 8,38 - oito reais e trinta e oito centavos), com restituição à vítima, estabelecimento comercial, admite-se a insignificância, excepcionando-se a condição de reiteração delitiva do agente. 4. Agravo regimental provido. Recurso especial a que se nega provimento. (STJ - AGRAVO REGIMENTAL NO RECURSO ESPECIAL AgRg no REsp 1377789 MG 2013/0127099-0. Data de publicação: 21/10/2014.

A educação fundamental como direito-dever permite, a partir da sua imanência, discutir a natureza das regras e dos princípios constitucionais considerando duas vertentes hermenêuticas distintas: a deontologia, voltada para os deveres e obrigações e a axiologia, ciência dos valores.

O cidadão que se vê diante de uma situação fática que lhe permite agir ou lhe proíbe de fazê-lo processa uma série de valores que fazem parte da sua vivência social. Desde cedo, a criança testa seus limites como a dizer para os adultos: "olha o que estou fazendo, ninguém vai me censurar? Eu sei que isso é errado, mas, se ninguém me impedir, vou fazer assim mesmo”. Uma criança de rua, abandonada a própria sorte, costuma agir da mesma forma. Mas o receptor torna-se a sociedade que o cerca. Esses limites axiológicos costumam nortear todas as relações sociais.

Para o senso comum, causa maior repreensão o fato de uma pessoa furtar um bem alheio. Não se pode dizer o mesmo, havendo, inclusive, uma excludente de ilicitude, do cidadão de bem que, para defender a sua família, mata um bandido dentro da sua residência. Não estaríamos diante de dois crimes, um dos quais é capital, ferindo o princípio do direito à vida? Nesse caso, quando está em jogo a noção de escolha do ser humano pelos valores morais, éticos, estéticos e espirituais, há de se levar em consideração o aspecto axiológico.

Considerando-se a dimensão axiológica, um pai e/ou uma mãe que faz (fazem) a escolha pelo ensino domiciliar estaria(m) abandonando os filhos à própria sorte? Não se estaria diante de uma situação contrária, de proteção, a considerar a liberdade axiológica de conduzir a educação moral, ética e religiosa dos filhos?

14 NEVES, 2013, passim

15 ALEXY, 2011, passim. 
Como visto, a questão do ensino domiciliar está longe de ser resolvida. Afinal, não se pode perder de vista que uma parcela da sociedade fez a opção de ela própria prover os estudos dos seus filhos. Nesse sentido, há, nitidamente, um conflito entre regras e princípios. Existe um regramento no Brasil que impede a prática. Essa nova tendência social acrescenta o viés principiológico ao caldeirão das possibilidades éticas.

O valor, ou aquilo que é valorizado pelas pessoas, é uma escolha individual, subjetiva e produto da cultura onde o indivíduo está inserido. Tanto o princípio quanto as regras submetem-se ao dever-ser como premissa de comportamento. Alexy destaca esse ponto que aproxima os princípios das regras, ou seja, a noção do dever-ser: "Princípios são, tanto quanto as regras, razões para juízos concretos de dever-ser, ainda que de espécie muito diferente. A distinção entre regras e princípios é, portanto, uma distinção entre duas espécies distintas" $"$.

A perspectiva axiológica adotada por Alexy em sua Teoria dos Direitos Fundamentais é criticada por não ter levado em conta o pluralismo social em virtude de não ter levado em conta as diferentes conjunturas das sociedades contemporâneas, que compartilham valores éticos intersubjetivamente. Habermas, citado por Marcelo Neves (2013), parece se aproximar mais dessa visão pluralista da sociedade, com base em perspectiva deontológica, assumindo a distinção entre princípios e valores.

Outra alternativa reside em definir o valor como preferência de um indivíduo ou de um grupo ou coletividade, o que nos põe, respectivamente, perante a ética individual e a ética política no sentido de Habermas. O que interessa aqui é a noção de valor ético-político (de uma coletividade). Nesse caso, apresenta-se a seguinte questão: "o que é bom para nós?". Trata-se do problema ético da forma particular de vida que é considerada boa para uma determinada coletividade. Habermas distingue esse problema da questão moral, referente a princípios (deontológicos) com pretensão de universalidade ${ }^{17}$.

Immanuel Kant também forneceu elementos para entender a deontologia, dividindo-a em dois conceitos: razão prática e liberdade. Para Kant, o dever-ser somente se estabelece, de fato, se estiver associado ao seu valor moral, que só pode ser atingida por uma livre vontade. Não se desvinculou a relevância da lei, mas a liberdade de obedecer à lei moral ganhou contornos de legitimação. O sentimento de obrigação deve estar harmonizado com as aspirações sociais, desde que não ofendam os princípios ligados à moral ${ }^{18}$.

O ensino domiciliar representa um direito-dever à educação fundamental dos filhos. O desejo de uma coletividade de ela própria prover a educação de seus filhos, baseada nos valores morais, éticos, religiosos e culturais deve ser entendido como uma maneira legítima de exercício da liberdade.

Esse mesmo princípio, pela própria experiência coletiva, costuma ser mitigado, pois implica uma interaplicação social. Para tanto, deve ser sopesada a sua noção de valor e desvalor em um critério mais ou menos objetivo de moralidade. A criação de um sindicato de criminosos para defender a liberdade de subtrair bens alheios supera a expectativa de moralidade social. Afinal se esbarra na liberdade que o cidadão tem de adquirir seus bens de maneira lícita e honesta. O contrário disso seria o caos social. O desvalor de tal hipótese reside no fato de existir um ganhador ilegítimo e um perdedor, que, nesse caso, é respaldado pela lei, quando ela lhe garante o direito à propriedade. Uma família que decide prover os estudos dos seus filhos a partir de suas convicções morais, filosóficas e religiosas não está, em tese, a provocar um desvalor. Pode-se dizer que as crianças ou adolescentes ficariam isoladas da possibilidade de ter acesso ao ensino acadêmico, por exemplo. Não se pode olvidar que o bilhete de entrada para as universidades ainda é proporcionado pelos vestibulares. E por que não considerar esse universo e lhes dar o direito de ingresso acadêmico via provas avaliativas? Não haveria um receio de o Estado por a prova sua competência quanto à política pública de oferecimento da educação fundamental ao admitir essa possibilidade pedagógica? Para responder a essa questão, não se deve pensar o ensino domiciliar simplesmente como concorrente, mas como alternativo ao modelo tradicional de ensino.

16 ALEXY, 2011, passim.

17 NEVES, 2013, passim

18 KANT, Immanuel. Crítica da razão prática. São Paulo: Escala, 2006 
A outra argumentação contrária ao ensino domiciliar diz respeito ao cerceamento dos filhos ao convívio comunitário. Ora, o ambiente escolar não pode ser considerado o único meio de convivência social. Existe, obviamente, uma infinita gama de possibilidades de interação humana proporcionada pelo lazer, cultura, religião, esporte, voluntariado. As redes sociais, também, podem representar uma importante ferramenta de comunicação entre os grupos de pessoas e diminuir sobremaneira esse isolamento provocado pela falta de convívio no ambiente escolar.

O Estado não pode desconsiderar o movimento adepto ao ensino doméstico. A simples exclusão desse grupo implica discriminação que não se coaduna com o Estado Democrático de Direito. As sociedades contemporâneas evoluem de forma dinâmica e imprevisível. Os mecanismos legais do Direito devem se harmonizar com essa dinâmica, sob pena de tornar o Direito anacrônico e autoritário. Criminalizar os pais que buscaram um modelo alternativo de efetivar seu dever quanto à educação dos seus filhos constitui medida jurídica desproporcional e desarrazoada.

O ensino fundamental deve ser entendido como direito-dever. As famílias concorrem para a concretização desse desígnio e podem colaborar harmonicamente nesse sentido. Os jovens submetidos à educação domiciliar podem ser matriculados no sistema estatal de ensino e, com isso, fazerem parte das estatísticas, podem receber material didático do Estado e ser avaliados periodicamente. Os pais, também, podem participar desse processo de interação e receber orientações de equipe pedagógica da escola além de ter a possibilidade de se fazer cursos de atualização de conteúdos. Seria uma maneira de romper o cabo de guerra formado pela divisão que colocou de um lado o Estado centralizador e provedor de tudo; de outro, as famílias que buscam uma alternativa de ensino aos seus filhos, baseado nas suas convicções morais, éticas, políticas, filosóficas e religiosas.

\section{Considerações finais}

Como visto, o direito-dever ao ensino fundamental costuma ser, tradicionalmente, atribuição do Estado sob o manto de uma interpretação do contexto normativo que conduziria à sua proibição. $\mathrm{O}$ movimento social, denominado mundialmente homeschooling, tem encontrado resistência por essa razão. $\mathrm{O}$ ensino domiciliar no Brasil, apesar disso, tem conseguido cada vez mais simpatizantes e adeptos. Pensando nessa ascensão, o Legislativo brasileiro tem discutido o assunto a partir do Projeto de Lei no 3179/2012. O Supremo Tribunal Federal, nessa esteira, perfilhou a constitucionalidade do ensino domiciliar e reconheceu a repercussão geral do tema.

Para pavimentar o caminho do entendimento, criou-se uma dicotomia, que, inevitavelmente, foi trazida à argumentação. O Estado provedor do ensino fundamental e as famílias que ministram conteúdos didáticos aos seus filhos, de acordo com suas convicções. Não se buscou falar em qualidade de ensino, apenas intentou-se trazer à baila um comportamento social, que não deve ser menosprezado. Para além disso, essa possibilidade pedagógica deve ser vista como aliada na formação educacional dos jovens brasileiros.

Enfim, na definição do conteúdo em favor do homeschooling pela via legislativa ou a conformação do conteúdo pela via judicial no âmbito da repercussão geral, não podem legisladores ou juízes desconsiderarem a composição do viés deôntico com o viés axilógico de modo a fazer evidenciar a condensação de uma expectativa social legítima no âmbito do Estado Democrático de Direito. Seja qual for a via de validação, não poderão ser desconsiderados, como aqui alvitramos, mecanismos de avaliação e de interação e inserção de pais e responsáveis.

Por esse caminho, o homeschooling longe de constituir uma ameaça à política pública de ensino fundamental do Estado brasileiro, se avulta como um plus para realizá-la. 


\section{ReferênCIAS BIBLIOGRÁFICAS}

ALEXY, Robert. Teoria Dos Direitos Fundamentais. 2a Ed. São Paulo: Malheiros, 2011.

ALMEIDA, Gregório Assagra de. Direito material coletivo: superação da summa divisio clássica direito público e direito privado por uma nova summa divisio constitucionalizada. Belo Horizonte: Del Rey, 2008.

ANDRADE, Édison Prado de. A educação familiar desescolarizada como um direito da criança e do adolescente: relevância, limites e possibilidades na ampliação do direito à educação. Tese de doutorado da Universidade de São Paulo (USP), orientação: Roberto da Silva, São Paulo: s.n., 2014. Disponível em: http:/ / www.teses.usp.br/teses/disponiveis/48/48134/tde-10112014-111617/pt-br.php. Acesso em 10/07/2015.

BONAVIDES, Paulo. Curso de Direito Constitucional. 29 ed. São Paulo: Malheiros, 2014.

BRASIL. Projeto de Lei no 3179/2012. Brasília: Câmara dos Deputados. Apresentado em 08/02/2012. Disponível em URL: http://www.camara.gov.br/proposicoesWeb/fichadetramitacao?idProposicao=534328. Acesso em 16 de julho de 2015.

BRASIL. Lei 8.069/1990, Estatuto da Criança e do Adolescente. Disponível em: http://www.planalto.gov. br/CCIVIL_03/leis/L8069.htm. Acesso em 15/07/2015.

BRASIL. Constituição da República Federativa do Brasil de 1988, disponível em: http://www.planalto.gov. br/ccivil_03/constituicao/constituicao.htm. Acesso em 16/07/2015.

BRASIL. Lei no 9.394, de 20 de dezembro de 1996, Lei de Diretrizes e Bases da Educação Nacional, disponível em: http://www.planalto.gov.br/ccivil_03/LEIS/L9394.htm. Acesso em 15/07/2015.

BRASIL. Parâmetros Curriculares Nacionais. Disponível em: http://portal.mec.gov.br/seb/arquivos/pdf/ livro01.pdf. Acesso em: 15/07/2015.

BRASIL. Parecer CNE/CEB no 34/2000. Disponível em: http://portal.mec.gov.br/cne/arquivos/pdf/ pceb34_00.pdf. Acesso em 15/07/2015.

BRASIL. Lei no 10.406, de 10 de janeiro de 2002, Código Civil. Disponível em: http://www.planalto.gov. br/ccivil_03/leis/2002/L10406.htm. Acesso em 15/07/2015.

CANOTILHO, José Joaquim Gomes. Direito Constitucional e Teoria da Constituição. Almedina: São Paulo. 2003.

Declaração Universal dos Direitos Humanos. Disponível em: http://www.dhnet.org.br/direitos/deconu/ textos/integra.htm. Acesso em 27/07/20015.

JELLINEK, Georg. Systerm der subjecktiven öffentlichen Rechte. Tübingen: Mohr, 1905.

JELLINEK, Georg. Allgemeine Staatslehre. Bad Homburg: Gentner, 1960.

KANT, Immanuel. Crítica da razão prática. São Paulo: Escala, 2006.

KOCH, Ingedore Vilaça; ELIAS, Maria Vanda. Ler e compreender os sentidos do texto. São Paulo: Contexto, 2006.

NEVES, Marcelo. Entre Hydra e Hércules. São Paulo: WMF Martins Fontes, 2013. 
Para publicar na revista Brasileira de Políticas Públicas, acesse o endereço eletrônico www.rbpp.uniceub.br

Observe as normas de publicação, para facilitar e agilizar o trabalho de edição. 